\title{
A Research on Teaching Reform of Higher Vocational Courses Related to Finance and Economics Based on Educational Informationization
}

\author{
Hongmei He \\ Accounting Institute, Chongqing business Vocational College, Chongqing, 400036, China
}

Keywords: Educational informationization. Higher vocational teaching. Finance and economics. Reform

\begin{abstract}
Finance and economics education is a special type in higher vocational education. With respect to its educational orientation, it should adapt to the requirement for cultivation of higher vocational students' basic professional quality and learning ability. Information era has come, so it is essential to pay attention to permeation of informatization in higher vocational colleges, especially in education related to finance and economics courses, in order to satisfy requirements of the society for finance and economics talent in the aspect of information technology. Thus, it is obvious that application of information technology to teaching of finance and economics courses at higher vocational colleges is of great and practical significance for improvement in teaching level. This thesis starts with necessity of teaching informatization reform of finance and economics courses at higher vocational colleges and discusses ways to apply information technology to finance and economics courses simply. Based on this, it explores measures of teaching reform.
\end{abstract}

\section{Introduction}

Higher vocation education in China has been developed for 30 years. During this period, higher vocational colleges pay much attention to orientation about cultivation of talent's comprehensive professional ability. Meanwhile, this decides higher vocational colleges' construction principles in the aspect of talent cultivation: based on cultivation of professional skills, demands of jobs are used as targets to establish schemes related to talent cultivation, design teaching methods and develop teaching courses, and basic methods of talent cultivation are post practice, school-enterprise cooperation and work-school combination. However, higher vocational education related to finance and economics has difference from other majors. Considering selection of talent cultivation modes, it cannot apply modes that value working process mechanically, for instance, post practice of the majors Science and Engineering. As modern economy develops rapidly, requirements of service industry, especially high-end service industry like finance and management, for employees are improved constantly. Therefore, while carrying out talent cultivation, higher vocational colleges should not only pay attention to cultivation of vocational and professional skills but also need cultivate higher vocational students' planning and decision-making ability in work and help students to improve their ability and quality in the aspects of self-adjustment, self-dependent innovation and teamwork comprehensively. Consequently, it is quite necessary to implement teaching reform in teaching of finance and economics courses at higher vocational colleges by relying on educational informationization.

\section{Necessity to apply information technology to teaching of finance and economics courses in higher vocational education}

As knowledge economy develops rapidly, information technology has been widely applied to all industries of the society. According to related statistics, contribution of information industry to Gross National Product (GNP) exceeded 10\% in 2012. Cognition of all countries' education industry for value of information education becomes profounder and profounder. Nowadays, informationization degree of America is the first of all. Such a position of America mainly benefits considerable development of information accomplishment education in national education. In the 1990s, America 
organized about 80 education sectors to establish information accomplishment forums in a wide range. In the corresponding period, Britain also established courses related to information accomplishment education in uniform courses of the country and paid much attention to information accomplishment education. However, development of China in this aspect has just started. Specifically, such courses are rarely established at research-based colleges. At colleges of higher vocational education, their key teaching points mainly focus on practical training. Thus, the degree to which they attach importance to information accomplishment education is rather low, which results in the situation that construction of schools' information platform libraries' informatization and data resource pools is backward. In addition, higher vocational colleges also lack uniform planning and guidance of national policies or management system. Importance of information construction at colleges of higher vocational education is mainly reflected by the following aspects:

Features of finance and economics majors decide information technology is a supporting point of teaching

During the course of our educational informationization, application of information technology to teaching of subject curriculum is a hot topic. At higher vocational colleges, cultivation of students from majors related to finance and economics, which pays attention to application of vocational skills and techniques to practice and application of information technology can be distinctly simulated by computer. In doing so, it enables higher vocational students' vocational skills to be practiced in virtual reality so that formation of higher vocational colleges' applied talent cultivation mode can be realized rapidly.

\section{Changing traditional teaching methods}

Application of information technology to teaching of finance and economics courses at higher vocation colleges can promote implementation of course reform and development of quality-oriented education, which lays a solid foundation for schools to create new-type learning environment that is different from traditional modes and establish resource sharing system. Besides, it can make students obtain information in the process of learning more conveniently and more flexibly, improve level of quality-oriented education and drive formation of students' creative thinking as well as independent discovery and exploration competence.

\section{Improving students' information accomplishment}

Currently, knowledge economy of China develops rapidly. Under the social background of information explosion, workers in the industry of economy, especially the ones in industries like accounting, finance and management, need have some information processing capability, learning ability and teamwork ability, critical thinking and problem-solving ability. Thus, cultivation of information accomplishment, which adapts to era development at present, should be added to the educational process of higher vocational colleges. At the same time, multimedia methods should be used to guide and help students to have comprehensive perception and cognition of learning objects.

\section{Ways to integrate information technology with finance and economics courses}

In the process in which information technology is integrated with finance and economics courses, we should utilize the following approaches to realize improvement in teaching level:

\section{Content of project teaching}

Study content of information technology courses carefully, use their features as bases and combine with specialized materials of finance and economics courses. Teachers should design teaching projects, combine key and difficult points in teaching knowledge with application of practical techniques, reflect them in teaching projects and provide directions of curricular and extra-curricular discovery learning for students.

\section{Process of inquiry teaching}

Making a thorough inquiry on teaching process is important content of educational reform, which reflects that students' dominant role in classroom teaching is determined. After specialized materials and information technology materials have been assembled and settled by teachers, they are set in teaching projects. Thus, students can obtain these kinds of information actively in the process of 
learning. Having mastered basic knowledge, students may explore problems, which they discover in the process of independent study, or directly discuss with classmates about such problems in classroom. Meanwhile, teachers participate in students' discussion to control directions of students' discussion in order to make previous inheritance-based teaching mode inquiry-type learning mode.

\section{Networking of teaching}

In previous teaching activities, teaching materials in the form of textbooks were main sources of teaching content. Being required by educational informationization, information technology has been widely applied to teaching activities, which enhances networking degree of teaching activities largely. In this case, students need exert their enthusiasm and initiative sufficiently in teaching activities, learn to obtain learning materials from network sources and enrich teaching content. Meanwhile, teachers should recombine and create teaching content boldly and help students develop the habit that they utilize network recourses to perform independent learning.

\section{Measures for teaching informatization reform of finance and economics courses at higher vocational colleges}

When higher vocational colleges carry out teaching informatization reform of finance and economics courses, the first problem they face with lies in how to improve students' information accomplishment and cultivate their information ability. Since finance and economics industry in the society proposes higher and higher requirements for workers' quality, higher vocational college need enhance cultivation of students' independent learning and innovation ability, improve students' information accomplishment and make students hold a dominant role in the process of information processing. Only in this way can personnel training mode of higher vocational colleges adapt to social requirements which are increasingly improved.

\section{Establishing interactive platforms and information resource pools for courses based on campus network}

Campus network $(\mathrm{CN})$ acts as an important media for learning communication between teachers and students and information distribution in campus. At the same time, CN connects information resources inside and outside higher vocational colleges and undertakes a heavy responsibility for information resource sharing. However, most of higher vocational colleges have little input into construction of $\mathrm{CN}$ at present, which causes development lag for informatization and results in the phenomenon that content of information resources in CN is lengthy and jumbled correlation among such resources is poor. As a result, the positive role that CN plays in the aspects of communication and learning between teachers and students and improvement in students' information accomplishment is not exerted sufficiently. To accelerate information construction, higher vocational colleges should start with the following aspects:

First of all, they should establish and perfect interaction platforms for courses. Establishment of interaction platforms for courses in CN can make students' learning and interaction with teachers break limitations caused by time and space, enhance extracurricular learning and communication between teachers and students, improve flexibility of students' learning in the aspects of time and place and realize implementation of teachers' long-distance coaching for students. This is also an important way to improve higher vocational students' information accomplishment.

Secondly, improve quality and level of network courses. In higher vocational schools' teaching reform carried out by the country, construction of high-quality network courses is significant content, which mainly directs at improving innovation of higher vocational education in education modes constantly, deepening teaching reform, promoting level of application of network information technology to course teaching, making information resources of finance and economics majors be shared on network widely and strengthening higher vocational students' overall quality and self-learning ability comprehensively.

Next, build teaching resource pools. Construction and application of teaching resource pools to higher vocational colleges can promote comprehensive improvement in learning ability of high 
vocational students. These resource pools include multimedia teaching courseware, teaching materials, teachers' teaching videos and finance and economics journals etc.

\section{Developing finance and economics database that are appropriate for students from finance and economics majors}

In daily study, students from finance and economics majors at higher vocational colleges need do a number of practical researches, which requires that there should be high-quality and sufficient financial and economical data to support implementation of data collection and reduction in the process of learning. In previous study, most of the data needed by practical researches of students derived from network. Such data are scattered and it is difficult to ensure their reliability, which have negative impacts on improvement in efficiency of students' daily learning to a large extent. Thus, higher vocational colleges need build financial and economic database with reliable sources as well as actual and efficient data for students in order to improve their learning efficiency and establish good information resource bases. Database should contain the following content: data about macro economy, financial data, economic news data and enterprises' industrial data etc. However, it is essential to input lots of funds and related professionals into establishment of database, which is a huge project. Thus, higher vocational colleges may choose to cooperate with commercial database to establish financial and economic database that is appropriate for students.

\section{Course teaching informatization}

Informationized course teaching means information technology is applied to all links of course teaching of subjects in order to realize application of information technology to teaching content, implementation process of courses and evaluation on teaching effect. In practical teaching of courses related to finance and economics, application of information technology like computer and multimedia is an important component of modern teaching methods in educational informationization. Take teaching of the major Accounting for example. It is a subject that attaches much importance to cultivation of students' ability. If multimedia accounting simulation laboratories can be used to implement demonstrative teaching and practical simulation in courses about Computerization, students can practice their practical ability and consolidate their theoretical knowledge in the process in which they use computer to finish financial accounting procedures step by step.

\section{Conclusion}

Under the situation that construction of educational informationization is promoted constantly in China, higher vocational colleges' teaching reform of courses related to finance and economics is a long-term task that need be developed with improvement in technological level of informatization and application of information technology in teaching. Initiative and subjective initiative of colleges, teachers and students in educational activities can be exerted sufficiently, national policies about educational informationization reform can be put into practice and students' comprehensive quality can be improved comprehensively only when measures of teaching reform are implemented practically, higher vocational colleges' teaching informatization is realized and level of students' information accomplishment is improved. Especially, in higher vocational education related to finance and economics, this is of important and practical significance for cultivation of versatile talent with splendid vocational skills and high information technology level.

\section{Acknowledgments}

This thesis is one of the staged achievements of A Research on Higher Vocational Education and Teaching Mode Centering on Space Teaching of Educational Informationization an educational science planning task of Chongqing City in 2013 (approval No. of the task: 2013-ZJ-063; compere: He Hongmei). 


\section{References}

[1] Yu Ying and Zou Junxia: Deepen Higher Vocational Colleges’ Teaching Reform \& Guarantee Realization of Objectives of Talent Training -Take Discussion on Economics Mathematics Course Teaching of Majors Related to Finance and Economics at Higher Vocational Colleges as An Example, Management Observer, 2013(6).

[2] Yu Bo: On Cultivation of Information Accomplishment Ability of sStudents from Majors Related to Finance and Economics at Higher Vocational Colleges under the Background of Informatization, Journal of Jinan Vocational College, 2012(12).

[3] Zhang Shuying: Thinking on Teaching Reform Modes in Finance and Economics Education, China Management Informatization, 2011(11).

[4] Peng Maoling and Tang Dongsheng: A Research on the Teaching mode Integrating Information Technology and Courses of Finance and Economics Majors at Higher Vocational Schools, Computer CD Software and Applications, 2013(15).

[5] Qiu Junru and Dong Ruili: Exploration of Construction of School-Enterprise Joint Training Based on Informatization on Finance and Economics Profession — Take the Finance Profession of Zhejiang Financial Vocational College for Example, Financial Education Research, 2013 (5)

[6] Zhou Yue: Impacts of Accounting Informationization on Cultivation of Accoutning Talent at Higher Vocational Schools, Friend of Accounting, 2010(8).

[7] Ju Chunhua and Zhou Yi: Discussion on Teaching Reform of Courses Integrating Information Technology Knowledge and Knowledge of Finance and Economics Majors Related, China Higher Education Research, 2009(12). 